\title{
ELECTROSTATIC SPRAYING EFFECT ON SPRAY DEPOSITION AND POWDERY MILDEW CONTROL IN SOYBEAN
}

\author{
Heli H. T. de Assunção ${ }^{1^{*}}$, Sérgio M. Silva ${ }^{2}$, Guilherme S. Alves ${ }^{3}$, Cesar H. S. Zandonadi ${ }^{4}$, \\ João P. A. R. da Cunha ${ }^{4}$
}

${ }^{1 *}$ Corresponding author. Universidade Federal de Mato Grosso/ Rondonópolis - MT, Brasil.

E-mail: heli.herosteodoro@gmail.com | ORCID ID: https://orcid.org/0000-0002-7575-1971

\author{
KEYWORDS \\ application rate, \\ droplet electrification, \\ application \\ technology, \\ Microsphaera diffusa
}

\begin{abstract}
Electrostatic spray can bring benefits to the pesticide application such as the reduction of application rate and the increase of deposits on targets. Therefore, this study aimed to evaluate the effect of electrostatic spraying using lower application rates and different adjuvants on soybean spray deposition and chemical control of powdery mildew (Microsphaera diffusa Cooke \& Peck). The field experiment was conducted in duplicate. A randomized complete block design with four replications in a $2 \times 2 \times 2+1$ factorial scheme was used. The factors were two application rates, with and without droplet electrification, two spray solution compositions, and one additional treatment. Deposition on upper and lower leaves, spray loss to the soil, and powdery mildew control effectiveness were evaluated. The electrical conductivity of the spray solution and the charge/mass ratio induced in droplets were also evaluated. All treatments reduced the soybean powdery mildew severity. Electrostatic spraying responded positively to an increase in the electrical conductivity of the spray solution regarding the charge/mass ratio, but it did not increase spray deposition on the lower third of the canopy and did not influence spray loss to the soil, which was higher as the application rate increased.
\end{abstract}

\section{INTRODUCTION}

Soybean (Glycine max L. Merrill) cultivation is of great importance in the world. Management of phytopathogenic organisms is necessary to maintain its productive potential, and, in this process, fungicide application technology is essential to combine agronomic effectiveness and environmental safety.

Leaf diseases are one of the major problems in soybean fields, such as powdery mildew, caused by the biotrophic fungus Microsphaera diffusa Cooke \& Peck (Amorim et al., 2018). Present at vegetative and reproductive crop growth stages, its infection rate is greater in air relative humidity above $50 \%$ and when soybeans are at reproductive stages [between R1 (beginning bloom) and R6 (full seed)] (Blum et al., 2002).

Under severe infection conditions, a control method is necessary because the fungus causes direct damage to the leaf tissue and prevents photosynthesis, resulting in prematurely falling dry leaves (Niero et al., 2007), which may cause yield losses ranging from 26 to $50 \%$, depending on the phenological stage at which infection occurs (Igarashi et al., 2010).

Strategies to improve the efficiency of pesticide applications include the sprayer equipment, spray solution characteristics, and operation planning. Currently, there is a tendency to reduce application rates in order to minimize operational costs (Cunha et al., 2018; Ferguson et al., 2016).

For this, alternative technologies have been used in the field. Among alternative application technologies used in the field to reduce carrier volumes, electrostatic spraying has been studied by some researchers (Cerqueira et al., 2017; Cunha et al., 2017a). Droplet electrification can increase spray deposition on targets and consequently pesticide efficacy at lower application rates when compared to conventional methods (Patel et al., 2017).

Adjuvants are another technology that may improve the application techniques. They alter the physicochemical properties of spray solutions (electrical conductivity, $\mathrm{pH}$, and surface tension) and may modify their deposition pattern on the desired target. Some adjuvants also may change droplet evaporation time, droplet size, contact angle,

\footnotetext{
${ }^{2}$ Universidade Federal dos Vales do Jequitinhonha e Mucuri/ Unaí - MG, Brasil.

${ }^{3}$ University of Nebraska-Lincoln/ North Platte, EUA.

${ }^{4}$ Universidade Federal de Uberlândia/ Uberlândia - MG, Brasil.

Received in: 5-26-2019

Accepted in: 7-22-2019
} 
wetting and spreading of the product on the leaves, as well as the electrical conductivity, $\mathrm{pH}$, and surface tension of the phytosanitary spray solution. (Cunha et al., 2017b).

Among the different characteristics that influence the application, the electrical conductivity of the spray solution may change the magnitude of droplet electrification. It may increase spray deposition on targets by increasing the attraction between droplets and target and hence, provide better biological efficacy (Law, 1983; Sasaki et al., 2015).

The number of studies involving pesticide application on soybean using electrostatic sprayers is limited. Most studies are carried out using aerial applications and the number is even lower when ground boom sprayers are associated with electrostatic systems. Thus, this study aimed to evaluate the effect of electrostatic spraying using lower application rates and different adjuvants on soybean spray deposition and powdery mildew control.

\section{MATERIAL AND METHODS}

Experiment was carried out at the Capim Branco Research Farm of the Federal University of Uberlândia
(UFU) in Uberlândia, MG, Brazil, to determine the electrical conductivity and droplet electrification capacity. The experiment was carried out in a completely randomized design with five treatments and four replications. Fungicides (azoxystrobin $-300 \mathrm{~g} \mathrm{~kg}^{-1}$ and benzovindiflupyr - $150 \mathrm{~g} \mathrm{~kg}^{-1}$, dispersible granules) were sprayed at two concentrations $\left(0.89\right.$ and $\left.2.96 \mathrm{~g} \mathrm{~L}^{-1}\right)$, tank-mixed or not with mineral oil at $0.5 \% \mathrm{v} \mathrm{v}^{-1}\left(\mathrm{OM}, 428 \mathrm{~g} \mathrm{~L}^{-1}\right.$ - low electrical conductivity adjuvant) and synthetic adjuvant at $0.05 \% \mathrm{v} \mathrm{v}^{-1}$ (SA, nitrogen - $34.5 \mathrm{~g} \mathrm{~L}^{-1}$, phosphorus $\left(\mathrm{P}_{2} \mathrm{O}_{5}\right)-207 \mathrm{~g} \mathrm{~L}^{-1}$, acidulant $-30.8 \mathrm{~g} \mathrm{~L}^{-1}$, and silicone surfactant $\left.-57.5 \mathrm{~g} \mathrm{~L}^{-1}\right)$. Water without any product was also used. Concentrations of these four spray solutions were defined in accordance with the manufacturers' recommendations and corresponded to those applied in the treatments of the experiment conducted later in the field. The treatment compositions are shown in Table 1.

Electrical conductivity was evaluated according to the methodology used by Cunha et al. (2017b). Measurements were performed directly on the solutions using a portable conductivity meter (AKSO, AK59, São Leopoldo, RS, Brazil). The equipment was calibrated before taking the readings using standard solutions provided by the manufacturer.

TABLE 1. Description of the composition of the evaluated spray solutions.

\begin{tabular}{cccc}
\hline Treatment & Fungicide $\left(\mathrm{g} \mathrm{L}^{-1}\right)$ & $\mathrm{MO}\left(\%, \mathrm{v} \mathrm{v}^{-1}\right)$ & ${\mathrm{SA}\left(\%, \mathrm{v} \mathrm{v}^{-1}\right)}$ \\
\hline $0.89 \mathrm{MO}$ & 0.89 & 0.5 & - \\
$0.89 \mathrm{SA}$ & 0.89 & - & 0.05 \\
$2.96 \mathrm{MO}$ & 2.96 & 0.5 & - \\
$2.96 \mathrm{SA}$ & 2.96 & - & 0.05 \\
Water & - & - & - \\
\hline
\end{tabular}

Fungicides: azoxystrobin $\left(300 \mathrm{~g} \mathrm{~kg}^{-1}\right)$ and benzovindiflupyr $\left(150 \mathrm{~g} \mathrm{~kg}^{-1}\right)$. MO: mineral oil of the aliphatic hydrocarbon chemical group (low electrical conductivity adjuvant). SA: synthetic adjuvant (high electrical conductivity adjuvant).

The influence of spray solutions on the droplet electrification system was verified by analyzing the charge/mass ratio $(\mathrm{Q} / \mathrm{M})$. A hydraulic boom sprayer (FMCopling, JB80 400 BR12, Araraquara, SP, Brazil) with a $12-\mathrm{m}$ boom, 24 nozzles spaced by $0.5 \mathrm{~m}$, and $400 \mathrm{~L}$ tank equipped with a droplet electrification system (SPE, Porto Alegre, RS, Brazil) was used. The boom had hollow cone spray tips named SPE 1 (flow rate of $0.265 \mathrm{~L} \mathrm{~min}^{-1}$ at 300 $\mathrm{kPa})$. The sprayer was mounted on an $85 \mathrm{hp}(62.5 \mathrm{~kW})$ tractor (Ursus, 2-85, Nova Petrópolis, RJ, Brazil). The working pressure was $300 \mathrm{kPa}$, and the regulated voltage of the equipment was $6.95 \mathrm{kV}$.

The number of charges of the system was determined by the Faraday cage method, as used by Tavares et al. (2017). Spray nozzle outlet was maintained at $0.05 \mathrm{~m}$ away from the cage opening. It was built in a galvanized steel cylindrical structure, wrapped with $3.033 \mathrm{~mm}$ opening wire mesh and $1.2 \mathrm{~mm}$ diameter wire. Dimensions of $0.8 \mathrm{~m}$ in diameter and $0.6 \mathrm{~m}$ in length were adopted to allow the entire spray jet to be captured by the cage. Cage insulation was promoted by a $1.6 \mathrm{~m}$ long wooden rod with $0.5 \mathrm{~m}$ of the rod below ground level. A 5-second wait was standardized after the sprayer started, and then it sprayed for $1 \mathrm{~min}$ inside the cage. After that, the amount of liquid sprayed was measured using a $5 \mathrm{~mL}$ precision graduated beaker. Spray solution density was also determined by the relationship between its mass and the sampled volume. Thus, the mass of liquid sprayed inside the cage was determined per unit time $\left(\mathrm{kg} \mathrm{s}^{-1}\right)$.

The measurement of the electric current in the jet of sprayed droplets was performed using a multimeter (Minipa $^{\circledR}$, ET-2517 ${ }^{\mathrm{a}}$, Joinville, SC, Brazil) connected to the cage and electrical grounding. The multimeter model used had a measurement range for electric current from zero to $600 \mu \mathrm{A}$ and an accuracy of $\pm 0.2 \%$. Multimeter grounding was performed by using a copper bar buried $2 \mathrm{~m}$ below ground level, similar to the methodology used by Tavares et al. (2017). Multimeter readings were taken in direct current mode. Thus, the electric current that the jet of sprayed droplets induced in the cage was determined to verify the Q/M through the relationship between the electric current and the amount of mass of the sprayed liquid $\left(\mathrm{kg} \mathrm{s}^{-1}\right)$, according to the equation $\mathrm{Q} / \mathrm{M}=\mathrm{i} / \mathrm{m}$, where $\mathrm{Q} / \mathrm{M}$ is the charge/mass ratio $\left.(\mathrm{mC} \mathrm{kg})^{-1}\right), i$ is the electric current contained in the spray jet $\left(\mathrm{mC} \mathrm{s}^{-1}\right)$, and $\mathrm{m}$ is the liquid flow $\left(\mathrm{kg} \mathrm{s}^{-1}\right)$ (Sasaki et al., 2015).

Environmental conditions were monitored during the experiment using a digital thermo-hygro-anemometer (Kestrel, 4000, Boothwyn, Pennsylvania, USA), with minimum and maximum temperatures of 26.9 and $30.0^{\circ} \mathrm{C}$, respectively, relative air humidity between 65 and $66.4 \%$, and wind speeds between 0.0 and $4.9 \mathrm{~km} \mathrm{~h}^{-1}$. 
A field experiment was conducted in two areas during the 2017/2018 growing season using the same products and equipment described above. The Area 1 was located at Capim Branco Research Farm of the Federal University of Uberlândia (UFU), Uberlândia, Minas Gerais, Brazil. The area has an elevation of 842 meters, geographical coordinates of $18^{\circ} 53^{\prime} 23.46^{\prime \prime} \mathrm{S}$ and $48^{\circ} 20^{\prime} 27.46^{\prime \prime} \mathrm{W}$, flat topography, and Aw climate according to the Köppen classification, defined as humid tropical with dry winter. The Area 2 was located in a commercial area located in the Tapuirama District, Uberlândia, Minas Gerais, with an altitude of 835 meters, geographical coordinates of $19^{\circ} 05^{\prime} 57.00^{\prime \prime} \mathrm{S}$ and $47^{\circ} 57^{\prime} 21.13^{\prime \prime} \mathrm{W}$, flat topography, and Aw climate according to the Köppen classification. In Area 1, soybean cultivar Nidera 6906 (super-early cycle and indeterminate growth habit) was sown on November 17, 2017, with $0.5-\mathrm{m}$ row spacing and 16 seeds per linear meter to obtain 320 thousand plants ha ${ }^{-1}$. In Area 2, the soybean cultivar was Nidera 7901 (early cycle and indeterminate growth habit), was sown on November 24,2017 , with 0.5 -m row spacing and 13 seeds per meter to obtain 260 thousand plants ha ${ }^{-1}$.

The experimental design used in the field was a randomized complete block design with 4 replications in a $2 \times 2 \times 2+1$ factorial scheme, with 2 application rates $(95$ and $52 \mathrm{~L} \mathrm{ha}^{-1}$ ), with or without droplet electrification, 2 spray solution compositions (fungicide $+\mathrm{OM}$ and fungicide + SA), and an additional treatment (control without application). Each plot consisted of $40 \mathrm{~m}^{2}$, with 10 rows of plants with $8 \mathrm{~m}$ long. The six middle rows, but without $2 \mathrm{~m}$ from each end, were considered as the useful plot for application technology and biological effectiveness evaluations. Deposition, spray loss to the soil, and effectiveness of the disease control were evaluated.

Applications were made on soybeans at R5.3 growth stage (grain filling) in both areas. Fungicides are classified by the manufacturer as systemic, belonging to strobilurin (a.i. azoxystrobin, $300 \mathrm{~g} \mathrm{~kg}^{-1}$ ) and pyrazole + carboxamide (a.i. benzovindiflupyr, $150 \mathrm{~g} \mathrm{~kg}^{-1}$ ) chemical groups. The used dose was $200 \mathrm{~g}$ of commercial product per hectare.

A blue tracer (Duas Rodas, Jaraguá do Sul, SC, Brazil) was added to the spray solutions at $400 \mathrm{~g} \mathrm{ha}^{-1}$ to be quantified by spectrophotometry. After application, two leaflets were randomly collected from 10 plants at each plot after application, one in the lower and another in the upper third, both close to the main stem. They were individually placed into plastic bags depending on the position and stored in a Styrofoam box.

In addition, a study of spray solution loss to the soil was carried out by placing a set of Petri dishes (cover + bottom) per plot. They were placed between rows in the middle of the plot. After application, the dishes were collected and stored in a thermal box for further laboratory analysis, as performed by Zandonadi et al. (2019).

Samples were processed at the Laboratory of Agricultural Mechanization (LAMEC) of the UFU. A 100 $\mathrm{mL}$ of distilled water was added to the plastic bags containing upper and lower leaflets. The bags were then shaken for 30 seconds to extract the dye from the samples. The evaluation of the dye deposited on the Petri dishes followed a similar procedure used for the leaflets, by adding $10 \mathrm{~mL}$ of distilled water in each dish. The liquid extracted from each sample was deposited in plastic cups, which were stored in a refrigerated place with light isolation for 24 hours for subsequent absorbance reading in a spectrophotometer (Biospectro, SP22, Curitiba, PR, Brazil) at $630 \mathrm{~nm}$ wavelength Absorbance data was converted into dye concentration $\left(\mathrm{mg} \mathrm{L}^{-1}\right)$ using a dye calibration curve.. By knowing the soybean leaflet area measured using a leaf area meter (LI-COR, LI-3100C, Lincoln, NE, USA) and Petri dish area, the data was converted into amount of dye $(\mu \mathrm{g})$ per area $\left(\mathrm{cm}^{2}\right)$.

Weather conditions were monitored during fungicide applications using a digital thermo-hygroanemometer (Kestrel, 4000, Boothwyn, PA, USA). For Area 1, minimum and maximum temperatures were 26.8 and $30.6^{\circ} \mathrm{C}$, respectively, relative air humidity was between 55 and $65 \%$, and wind speeds ranged from 3.4 to $7.9 \mathrm{~km} \mathrm{~h}^{-1}$. For Area 2, minimum and maximum temperatures were 29.5 and $31.0^{\circ} \mathrm{C}$, relative air humidity ranged from 49 to $59 \%$, and wind speeds ranged from 2.1 to $4.6 \mathrm{~km} \mathrm{~h}^{-1}$.

The percentage of soybean leaf area affected by powdery mildew was measured for severity analyses, in which one evaluation was carried out before application, and the subsequent two evaluations at intervals of seven days after application. The severity was quantified using the diagrammatic scale proposed by Polizel \& Juliatti (2010). Ten leaves from the upper third and other ten from the lower third were evaluated in each plot The percentages of control were calculated comparing the severity of disease from treated and untreated plots.

Data were initially submitted to the Shapiro-Wilk, Levene, and Tukey's tests for normality distribution of residuals, homogeneity of variances and block additivity, respectively. After the assumptions were tested, the F-test was performed by analysis of variance and multiple comparisons of means were performed by the Tukey's test. Also, a contrast with the control treatment was performed when applicable by the Dunnett's test. All tests were carried out at $5 \%$ probability with the software R (R Core Team, 2018).

\section{RESULTS AND DISCUSSION}

The addition of fungicide and adjuvants produced changes in electrical conductivity $(\mathrm{EC})$ and $\mathrm{Q} / \mathrm{M}$ in relation to water (Table 2). EC is a parameter related to electrostatic spraying, which is capable of altering the electrification capacity of the sprayed droplets (charge/mass ratio) (Patel et al., 2017). This relationship was observed for all treatments when comparing the $\mathrm{EC}$ and $\mathrm{Q} / \mathrm{M}$ values of the spray solutions $0.89 \mathrm{MO}, 0.89 \mathrm{SA}, 2.96 \mathrm{MO}$, and $2.96 \mathrm{SA}$ with water.

The spray solution 2.96SA produced the highest values of $\mathrm{EC}$ and $\mathrm{Q} / \mathrm{M}$. On the other hand, the alteration of mineral oil by synthetic adjuvant at the lower fungicide concentration $(0.89 \mathrm{MO}$ and $0.89 \mathrm{SA})$ increased EC of the spray solution but did not result in higher Q/M. Possibly, it was due to the interaction with fungicide concentration since spray solutions with higher concentrations $(2.96 \mathrm{MO}$ and 2.96SA) showed an increase of Q/M. However, when comparing it with water, $\mathrm{EC}$ elevation promotes increased charge. Values around $12 \mathrm{mC} \mathrm{kg}^{-1}$ are considered ideal, and the beneficial effects on the amount and distribution of the active ingredient deposited on the target increase as $\mathrm{Q} / \mathrm{M}$ increases (Law, 1983). 
Sasaki et al. (2015) tested different adjuvants and their efficiency in droplet electrification of an electrostatic sprayer subjected to a constant flow rate of $0.150 \mathrm{~L} \mathrm{~min}^{-1}$ and at a distance of $0.1 \mathrm{~m}$ from the Faraday cage. The authors found $\mathrm{Q} / \mathrm{M}$ values of 4.88 and $5.45 \mathrm{mC} \mathrm{kg}^{-1}$ in spray solutions of 227.50 and $607.50 \mu \mathrm{S} \mathrm{cm}^{-1}$, respectively. These values are lower compared to those found in this study, possibly due to the difference in the distance that the nozzle was positioned in relation to the target $(0.1 \mathrm{~m}$ and $0.05 \mathrm{~m})$ and equipment model tested.

TABLE 2. Physicochemical properties and charge/mass ratio of spray solutions.

\begin{tabular}{ccc}
\hline Spray solution & $\begin{array}{c}\mathrm{EC} \\
\left(\mu \mathrm{S} \mathrm{cm}^{-1}\right)\end{array}$ & Charge to mass ratio $\left(\mathrm{mC} \mathrm{kg}^{-1}\right)$ \\
\hline $0.89 \mathrm{MO}$ & $231 \mathrm{~d}$ & $10.39 \mathrm{~b}$ \\
$0.89 \mathrm{SA}$ & $342 \mathrm{~b}$ & $9.74 \mathrm{c}$ \\
$2.96 \mathrm{MO}$ & $305 \mathrm{c}$ & $9.41 \mathrm{~d}$ \\
$2.96 \mathrm{SA}$ & $528 \mathrm{a}$ & $12.19 \mathrm{a}$ \\
Water & $16 \mathrm{e}$ & $0.07 \mathrm{e}$ \\
\hline CV $(\%)$ & 4.49 & 1.66 \\
p-value & $1.8510^{-17 * *}$ & $4.9710^{-23 * *}$ \\
\hline
\end{tabular}

Means followed by the same letter in the column do not differ from each other by the Tukey test at $5 \%$ probability; CV $=$ coefficient of variation; $* *$ significant at $1 \%$ probability.

Spray solutions: $0.89 \mathrm{MO}$ - water + fungicide $\left(0.89 \mathrm{~g} \mathrm{~L}^{-1}\right)+$ mineral oil $\left(0.5 \% \mathrm{v} \mathrm{v}^{-1}, \mathrm{MO}\right) ; 0.89 \mathrm{SA}-$ water + fungicide $(0.89 \mathrm{~g} \mathrm{~L}-1)+$ synthetic adjuvant $\left(0.05 \% \mathrm{v} \mathrm{v}^{-1}, \mathrm{SA}\right) ; 2.96 \mathrm{MO}$ - water + fungicide $\left(2.96 \mathrm{~g} \mathrm{~L}^{-1}\right)+$ mineral oil $\left(0.5 \% \mathrm{v} \mathrm{v}^{-1}, \mathrm{MO}\right) ; 2.96 \mathrm{SA}-$ water + fungicide $(2.96 \mathrm{~g} \mathrm{~L}-1)$ + synthetic adjuvant $\left(0.05 \% \mathrm{v} \mathrm{v}^{-1}, \mathrm{SA}\right)$.

\section{Area 1}

Only the results regarding significant variables in relation to treatments were presented here, either alone or as a function of interactions.

The upper third of plants located in Area 1 showed values for both spray solution compositions that did not differ regarding the conventional technique (Table 3 ). The spray solution composed by the adjuvant with MO showed no difference between conventional and electrostatic applications. Also, no difference was observed between spray solutions, demonstrating that an increase in their EC did not interfere with the conventional technique. A difference was observed when comparing the electrostatic with the conventional technique with the use of the adjuvant that increased EC (SA), the latter being lower than the former. The increase in $\mathrm{EC}$ was decisive to improve the deposition values of the electrostatic technique, corroborating with Sasaki et al. (2015) and Patel et al. (2017). Higher EC values are beneficial to the electrostatic technique because they change the amplitude of droplet electrification, with direct impact on their attraction and higher spray deposition on targets and, consequently, higher effectiveness (Patel et al., 2017). Moreover, the addition of specific adjuvants to the spray solution can change EC values and hence $\mathrm{Q} / \mathrm{M}$ (Sasaki et al., 2015).

TABLE 3. Blue dye deposition on soybean leaves $\left(\mu \mathrm{g} \mathrm{cm}^{-2}\right)$ in the upper third after the different application techniques and spray solution compositions.

\begin{tabular}{ccc}
\hline Application technique & \multicolumn{2}{c}{ Spray solution } \\
\cline { 2 - 3 } & MO & $1023.27 \mathrm{aB}$ \\
\hline Conventional & $1206.80 \mathrm{aA}$ & $1432.27 \mathrm{aA}$ \\
\hline Electrostatic & $1136.71 \mathrm{bA}$ & \\
\hline $\mathrm{CV}(\%)=22.95$ & & \\
\hline
\end{tabular}

Means followed by the same lowercase letter in the row or uppercase letter in the column do not differ from each other by the Tukey test at $5 \%$ probability; $\mathrm{CV}=$ coefficient of variation; $\mathrm{MO}=$ mineral oil; $\mathrm{SA}=$ synthetic adjuvant.

No difference was observed between treatments for spray deposition on the lower third of plants, which can be attributed to plant architecture, causing great difficulty of penetration of droplets in the canopy due to the dense leaf mass at the application stage, making it difficult for product to reach the bottom of the plant.

The averages of spray loss to the soil (Table 4) had significant interaction between spray composition and application technique, with MO showing higher values when compared to SA in the conventional application. The spray loss was similar in the electrostatic application for both spray compositions. The electrostatic spraying has been shown to reduce the loss of products to the soil (Zhou et al., 2012), but this reduction was not observed here. It may have occurred due to the canopy closure at the application stage, which made it difficult for the droplets to penetrate it. 
TABLE 4. Blue dye deposition on Petri dishes $\left(\mu \mathrm{g} \mathrm{cm}^{-2}\right)$ arranged as an artificial target to estimate the loss to the soil after different application techniques and spray solution compositions.

\begin{tabular}{ccc}
\hline \multirow{2}{*}{ Application technique } & \multicolumn{2}{c}{ Spray solution } \\
\cline { 2 - 3 } & MO & SA \\
\hline Conventional & $467.08 \mathrm{aA}$ & $309.98 \mathrm{bA}$ \\
Electrostatic & $327.70 \mathrm{aA}$ & $449.48 \mathrm{aA}$ \\
\hline $\mathrm{CV}(\%)=36.89$ & & \\
\hline
\end{tabular}

Means followed by the same lowercase letter in the row or uppercase letter in the column do not differ from each other by the Tukey test at $5 \%$ probability; $\mathrm{CV}=$ coefficient of variation; $\mathrm{MO}=$ mineral oil; $\mathrm{SA}=$ synthetic adjuvant.

Before the application, the disease was equally distributed throughout the area, and severity in the lower third was numerically higher than that found in the upper third (63.8 and $15.3 \%$, respectively). In general, no significant difference was detected between treatments for severity in the performed evaluations. There was only difference in powdery mildew severity for the different application techniques in the lower third of plants at 14 days after application (DAA). However, all treatments showed a reduction in disease severity, confirming that the product reached the target (Table 5).

Product deposition on the target is essential to reduce the disease (Tormen et al., 2012). Strobilurins have low translocation in the plant and high lipophilicity. It indicates, therefore, the importance of an appropriate spray deposition for disease control (Santos et al., 2018).

TABLE 5. Percentage of powdery mildew severity according to diagrammatic scale and relative control for different treatments in the upper and lower thirds of plants at 7 and 14 days after application (DAA).

\begin{tabular}{ccccc|cccc}
\hline & \multicolumn{3}{c|}{ Upper third } & \multicolumn{3}{c}{ Lower third } \\
Treatment & \multicolumn{2}{c}{7 DAA } & \multicolumn{2}{c}{14 DAA } & \multicolumn{2}{c}{7 DAA } & \multicolumn{2}{c}{14 DAA } \\
& $\begin{array}{c}\text { Severity } \\
(\%)\end{array}$ & $\begin{array}{c}\text { Control } \\
(\%)\end{array}$ & $\begin{array}{c}\text { Severity } \\
(\%)\end{array}$ & $\begin{array}{c}\text { Control } \\
(\%)\end{array}$ & $\begin{array}{c}\text { Severity } \\
(\%)\end{array}$ & $\begin{array}{c}\text { Control } \\
(\%)\end{array}$ & $\begin{array}{c}\text { Severity } \\
(\%)\end{array}$ & $\begin{array}{c}\text { Control } \\
(\%)\end{array}$ \\
\hline $0.89 \mathrm{MO} \mathrm{C}$ & $10.0^{*}$ & 83 & $8.7^{*}$ & 87 & $37.1^{*}$ & 45 & $25.5^{*}$ & 71 \\
$0.89 \mathrm{MO}$ E & $12.9^{*}$ & 79 & $11.0^{*}$ & 83 & $39.0^{*}$ & 42 & $21.6^{*}$ & 75 \\
$0.89 \mathrm{SA} \mathrm{C}$ & $16.9^{*}$ & 71 & $11.5^{*}$ & 83 & $36.6^{*}$ & 46 & $23.8^{*}$ & 73 \\
$0.89 \mathrm{SA} \mathrm{E}$ & $11.5^{*}$ & 81 & $8.1^{*}$ & 87 & $33.1^{*}$ & 50 & $14.1^{*}$ & 84 \\
$2.96 \mathrm{MO} \mathrm{C}$ & $11.0^{*}$ & 81 & $12.9^{*}$ & 81 & $37.8^{*}$ & 45 & $26.0^{*}$ & 70 \\
$2.96 \mathrm{MO} \mathrm{E}$ & $12.9^{*}$ & 78 & $12.1^{*}$ & 81 & $40.4^{*}$ & 41 & $17.1^{*}$ & 81 \\
$2.96 \mathrm{SA} \mathrm{C}$ & $13.6^{*}$ & 77 & $9.7^{*}$ & 85 & $27.9^{*}$ & 59 & $16.0^{*}$ & 82 \\
$2.96 \mathrm{SA} \mathrm{E}$ & $22.1^{*}$ & 61 & $10.5^{*}$ & 85 & $33.9^{*}$ & 49 & $17.8^{*}$ & 80 \\
\hline Control & 59.9 & 0 & 67.3 & 0 & 67.5 & 0 & 88.6 & 0 \\
\hline CV & 15.81 & & 11.63 & & 8.45 & & 11.92 & \\
\hline
\end{tabular}

Means followed by asterisk differ from the control by the Dunnett test at $5 \%$ probability. $\mathrm{CV}=$ coefficient of variation. Severity is according to the diagrammatic scale of Polizel \& Juliatti (2010). Control is relative to the control treatment. Treatments: $0.89 \mathrm{MO} \mathrm{C}-$ water + fungicide

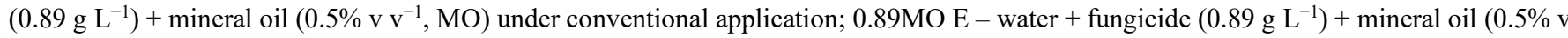
$\left.\mathrm{v}^{-1}, \mathrm{MO}\right)$ under electrostatic application; 0.89SA C - water + fungicide $\left(0.89 \mathrm{~g} \mathrm{~L}^{-1}\right)+$ synthetic adjuvant $\left(0.05 \% \mathrm{v} \mathrm{v}^{-1}\right.$, SA) under conventional application; 0.89SA E - water + fungicide $\left(0.89 \mathrm{~g} \mathrm{~L}^{-1}\right)+$ synthetic adjuvant $\left(0.05 \% \mathrm{v} \mathrm{v}^{-1}, \mathrm{SA}\right)$ under electrostatic application; $2.96 \mathrm{MO} \mathrm{C}-$ water + fungicide $\left(2.96 \mathrm{~g} \mathrm{~L}^{-1}\right)+$ mineral oil $\left(0.5 \% \mathrm{v} \mathrm{v}^{-1}, \mathrm{MO}\right)$ under conventional application; $2.96 \mathrm{MO} \mathrm{E}-$ water + fungicide $(2.96 \mathrm{~g} \mathrm{~L}-1)+$ mineral oil $\left(0.5 \% \mathrm{v} \mathrm{v}^{-1}, \mathrm{MO}\right)$ under electrostatic application; $2.96 \mathrm{SA} \mathrm{C}-$ water + fungicide $\left(2.96 \mathrm{~g} \mathrm{~L}^{-1}\right)+$ synthetic adjuvant $(0.05 \% \mathrm{v} \mathrm{v}-1, \mathrm{SA})$ under conventional application; 2.96SA E - water + fungicide $\left(2.96 \mathrm{~g} \mathrm{~L}^{-1}\right)+$ synthetic adjuvant $\left(0.05 \% \mathrm{v} \mathrm{v}^{-1}\right.$, SA) under electrostatic application.

All treatments had a significant difference in relation to the additional treatment (control without application), with the severity values of 59.9 and $67.3 \%$ for the control in the upper third and 67.5 and $88.6 \%$ for the control in the lower third at 7 and 14 DAA, respectively. No difference was observed between spray depositions on the lower third of plants, in accordance with the data of disease control. These data showed that the fungicide acted equally in the lower third region, reaching an average control for all treatments of $47 \%$, while the upper third presented an average control of $77 \%$, both at 7 DAA. In addition, control values for the third lower at 7 DAA were numerically lower when compared to the upper third. It represents a difficulty for droplets to penetrate the canopy, which favors the disease incidence (Heiffig et al., 2006).

The electrostatic system had a better performance when compared to the conventional system regarding disease control in the lower third at 14 DAA, showing that deposition evaluation methods at this plant position were unable to accurately estimate the behavior of electrified droplets in the crop canopy (Table 6). 
TABLE 6. Percentage of powdery mildew severity, according to the diagrammatic scale for different application techniques in the lower third of plants at 14 days after fungicide application.

\begin{tabular}{cc}
\hline Application technique & Severity $(\%)$ \\
\hline Conventional & $22.8 \mathrm{~B}$ \\
Electrostatic & $17.6 \mathrm{~A}$ \\
\hline $\mathrm{CV}(\%)=11.92$ & \\
\hline
\end{tabular}

Means followed by the same letter in the column do not differ from each other by the Tukey test at $5 \%$ probability. CV $=$ coefficient of variation.

\section{Area 2}

The analysis of the data of spray deposition on the upper third of plants showed only a significant difference for application rate variation (Table 7). This variation was approximately 2.08 -fold smaller at the lowest application rate, which is very close to the difference between the two adopted rates, i.e., 1.82-fold. Farinha et al. (2009) observed the correspondence of the reduction of deposition values as the application rate reduced.

TABLE 7. Blue dye deposition on soybean leaves $\left(\mu \mathrm{g} \mathrm{cm}^{-2}\right)$ of the upper third as a function of application rates.

\begin{tabular}{cc}
\hline $\begin{array}{c}\text { Application rate } \\
\left(\mathrm{L} \mathrm{ha}^{-1}\right)\end{array}$ & $\begin{array}{c}\text { Deposition } \\
\left(\mu \mathrm{cm}^{-2}\right)\end{array}$ \\
\hline 95 & $1411.57 \mathrm{~A}$ \\
52 & $766.46 \mathrm{~B}$ \\
\hline
\end{tabular}

$$
\mathrm{CV}(\%)=35.81
$$

Means followed by the same letter in the column do not differ from each other by the Tukey test at $5 \%$ probability. CV $=$ coefficient of variation.

Dye deposition on the lower third of plants showed an interaction between application technique and rate (Table 8). This interaction showed that the conventional application had better results for the application rate of $95 \mathrm{~L}$ $\mathrm{ha}^{-1}$ compared to the electrostatic application. These results also indicate that conventional application reduced the deposition values as the application rate decreased. However, it was not observed in the electrostatic application, allowing inferring that, for it, although responding less to higher application rates when compared to the conventional system, it does not present significant difference of dye deposition when subjected to a reduction of the application rate. Cerqueira et al. (2017) used conventional and electrostatic application rates of 800 and $40 \mathrm{~L} \mathrm{ha}{ }^{-1}$, respectively, on chrysanthemum plants (Dendranthema grandiflora T.) and found no difference in dye deposition on the lower third of plants.

Deposition values for both thirds of the plant (Tables 7 and 8) showed a decrease of 2.9-fold for the rate of $95 \mathrm{~L}$ $\mathrm{ha}^{-1}$ and 2.3 -fold for the rate of $52 \mathrm{~L} \mathrm{ha}^{-1}$ in the deposition on the lower third in relation to the upper third. This reduction in deposition on the lower thirds of the soybean canopy has been found in other studies and is due to the physical barrier that the upper leaf layers of the canopy impose on the droplets, making it difficult to penetrate the lower layers (Cunha et al., 2011; Tormen et al., 2012).

TABLE 8. Blue dye deposition on soybean leaves $\left(\mu \mathrm{g} \mathrm{cm}^{-2}\right)$ of the lower third after different techniques and application rates.

\begin{tabular}{ccc}
\hline & & \multicolumn{2}{c}{$\begin{array}{c}\text { Application rate } \\
\left(\mathrm{L} \mathrm{ha}^{-1}\right)\end{array}$} \\
\cline { 2 - 3 } Application technique & 95 & 52 \\
\hline Conventional & $561.18 \mathrm{aA}$ & $318.33 \mathrm{bA}$ \\
Electrostatic & $421.92 \mathrm{aB}$ & $357.83 \mathrm{aA}$ \\
\hline CV $(\%)=28.79$ &
\end{tabular}

Means followed by the same lowercase letter in the row and uppercase letter in the column do not differ from each other by the Tukey test at $5 \%$ probability. $\mathrm{CV}=$ coefficient of variation.

Application rate was the only factor that influenced spray loss to the soil (Table 9). The electrostatic spraying is an alternative to improve spray solution deposition on targets, promoting, among other benefits, the possibility of reducing the application rate (Cerqueira et al., 2017). However, regarding the reduction of losses to the soil, the highest loss values occurred in the plots that received the highest application rates, with no influence of the technique.

Regarding the evaluation of disease control in Area 2 , no significant levels that allowed the evaluation through diagrammatic scales were detected. 
TABLE 9. Dye deposition on Petri dishes $\left(\mu \mathrm{g} \mathrm{cm}^{-2}\right)$ arranged as an artificial target to estimate the loss to the soil after application at different rates.

\begin{tabular}{cc}
\hline Application rate $\left(\mathrm{L} \mathrm{ha}^{-1}\right)$ & Deposition \\
\hline 95 & $416.12 \mathrm{~A}$ \\
52 & $175.60 \mathrm{~B}$ \\
\hline
\end{tabular}

$\mathrm{CV}(\%)=57.13$

Means followed by the same letter in the column do not differ from each other by the Tukey test at $5 \%$ probability. CV $=$ coefficient of variation.

The application in both areas showed different behaviors of spray deposition probably because the crop population and plant architecture. Tormen et al. (2012) performed applications on soybean plants at R1 and R4 stages in two different cultivars and concluded that the difference in the leaf area index of these cultivars affected the droplet deposition in their canopy.

\section{CONCLUSIONS}

The increased electrical conductivity produced by the adjuvant increased the $\mathrm{Q} / \mathrm{M}$ of the sprayed droplets and led to an increase of spray deposition for the electrostatic technique on the upper third of soybean plants in one of the studied areas.

The fungicide azoxystrobin + benzovindiflupyr reduced the severity of soybean powdery mildew regardless of the adjuvant and application rate, while electrostatic spraying increased control in the lower third of plants.

The electrostatic spraying did not influence spray solution loss to the soil, which were higher at higher application rates.

\section{ACKNOWLEDGEMENTS}

The authors would like to thank FAPEMIG (Research Foundation of the State of Minas Gerais), CNPq (National Council of Scientific and Technological Development) and CAPES (Coordination for the Improvement of Higher Education Personnel) for the financial support.

\section{REFERENCES}

Amorim L, Rezende JAM, Bergamin Filho A (2018) Manual de fitopatologia. São Paulo, Agronômica Ceres, $573 \mathrm{p}$.

Blum LEB, Reis EF, Prade AG, Tavela VJ (2002) Fungicidas e mistura de fungicidas no controle do oídio da soja. Fitopatologia Brasileira 27:216-218.

Cerqueira DTR, Raetano CG, Dal Pogetto MHFA, Carvalho MM, Prado EP, Costa SIA, Moreira CAF (2017) Optimization of spray deposition and Tetranychus urticae control with air assisted and electrostatic sprayer. Scientia Agricola 74(1):32-40.

Cunha JPAR, Farnese AC, Olivet JJ, Villalba J (2011) Deposição de calda pulverizada na cultura da soja promovida pela aplicação aérea e terrestre. Engenharia Agrícola 31(2):343-351.

Cunha JPAR, Barizon RRM, Ferracini VL, Assalin MR (2017a) Spray drift and caterpillar and stink bug control from aerial applications with electrostatic charge and atomizer on soybean crop. Engenharia Agrícola 37(6):1163-1170.
Cunha JPAR, Alves GS, Marques RS (2017b) Tensão superficial, potencial hidrogeniônico e condutividade elétrica de caldas de produtos fitossanitários e adjuvantes. Revista Ciência Agronômica 48(2):261-270.

Cunha JPAR, Victor, AP, Sales CGR (2018) Spray deposition on soybean crop using different travel speeds and application rates. Engenharia Agrícola 38(1):82-87.

Farinha JV, Martins D, Costa NV, Domingos VD (2009) Deposição da calda de aplicação em cultivares de soja no estádio R1. Ciência Rural 39(6):1738-1744.

Ferguson JC, Chechetto RG, Hewitt AJ, Chauhan BS, Adkins ST, Kruger GR, O'Donnell CC (2016) Assessing the deposition and canopy penetration of nozzles with different spray qualities in an oat (Avena sativa L.) canopy. Crop Protection 81(1):14-19.

Heiffig LS, Câmara GMS, Marques LA, Pedroso DB, Piedade SMS (2006) Fechamento e índice de área foliar na cultura da soja em diferentes arranjos espaciais. Bragantia 65(2):285-295.

Igarashi S, Oliveira GM, Camargo LCM, Falkoski Filho J, Gardiano CG, Balan MG (2010) Danos causados pela infecção de oídio em diferentes estádios fenológicos da soja. Instituto Biológico de São Paulo 77(2):245-250.

Law SE (1983) Electrostatic Pesticide Spraying: Concepts and Practice. Transactions on Industry Applications 19(2):160-168.

Niero AR, Tratch R, Pinto Junior AR (2007) Eficácia dos fungicidas no controle de doenças de final de ciclo (DFC) da soja. Revista Academica 5:19-25.

Patel MK, Praveen B, Sahoo HK, Patel B, Kumar A, Singh M, Nayak MK, Rajan P (2017) An advance air-induced air-assisted electrostatic nozzle with enhanced performance. Computers and Electronics in Agriculture 135:280-288.

Polizel AC, Juliatti FC (2010) Quantificação de doenças foliares da soja por escalas diagramáticas. Enciclopédia Biosfera 6(11):1-9.

R Core Team (2018) R: a language and environment for statistical computing. R Foundation for Statistical Computing. Vienna.

Santos FH, Santos LA, Faria CMDR (2018) Translocação de triazóis e estrobilurinas no controle do oídio da soja. Pesquisa Aplicada \&Agrotecnologia 11(1):87-92.

Sasaki RS, Teixeira MM, Santiago H, Madureira RP, Maciel CFS, Fernandes HC (2015) Adjuvantes nas propriedades físicas da calda, espectro e eficiência de eletrificação das gotas utilizando a pulverização eletrostática. Ciência Rural 45(2):274-279. 
Tavares RM, Cunha JPAR, Alves TC, Alves GS, Silva JER (2017) Estudo de um sistema de eletrificação de gotas em pulverizador costal pneumático pelo método de gaiola de Faraday. Revista Ceres 64(5):476-485.

Tormen NR, Silva FDL, Debortoli MP, Uebel JD, Fávera DD, Balardin RS (2012) Deposição de gotas no dossel e controle químico de Phakopsora pachyrhizi na soja. Revista Brasileira de Engenharia Agrícola e Ambiental 16(7):802-808.
Zandonadi CHS, Alves TC, Assunção HHT, Alves GS, Silva SM, Cunha JPAR (2019) Tank mixture of pesticides and foliar fertilizes for Triozoida limbate control in guava trees (Psidium guajava L.). Revista Ceres 66(3):159-162.

Zhou Y, Qi L, Jia S, Zheng X, Meng X, Tang Z, Shen C (2012) Development and application prospects of pneumatic electrostatic sprayer in orchard. Asian Agricultural Research 4(1):78-80. 